\title{
症例報告
}

\section{ケタミン麻酔による子宮鏡検查時に 気道出血を起こした気管支拡張症の1例}

$\begin{array}{lll}\text { 松本睦子* } & \text { 石川麻子* } & \text { 仁熊敬枝* } \\ \text { 八井田 豊* } & \text { 大川雅廣* } & \text { 佐藤健治* }\end{array}$

[要旨] 子宮体癌の疑いで子宮鏡検査が予定され，ジアゼパム 3.5mg を静注し，2 分後にケタミン $30 \mathrm{mg}$ を静注した直後に気道出血のために気道閉塞を生じた症例を 経験した．患者は 76 歳で気管支拡張症を合併していたが，ときどきわずかな血痰を 認める以外に自覚症状はなかった．気道出血の原因として，術前の気道感染により易 出血性になっていたこと, ジアゼパム投与後のケタミン静注により呼吸抑制, 舌根沈 下をきたし低酸素血症 $\left(\mathrm{SpO}_{2} 55 \%\right)$ ，高二酸化炭素血症となったこと，加えてケ タミンの交感神経刺激作用により血圧が上昇（206/1 16mm H ）したことが考え られた. 気管支鏡の時点では出血は止まっていたが予防的にトロンビンの投与を行っ た. 気管支拡張症では自覚症状がない場合でも麻酔管理には注意を要すると思われた。 キーワード: 気管支拡張症, 気道出血, ケタミン

（日臨麻会誌 Vol.23 No.2, $39 ＼mathrm{~ 42, ~ 2003) ~}$

\section{はじめに}

気管支拡張症は気管支内腔の慢性，非可逆的な拡 張をきたす病態 ${ }^{1)}$ と定義されている，今回，子宮体 癌の疑いにより子宮鏡検査，子宮内膜掻爬術を行う 際の麻酔に，ジアゼパム，ケタミンを投与した直後 より気道出血をきたし，気道閉塞に陥つた気管支拡 張症合併患者を経験した。

\section{I 症例}

76 歳, 女性. 身長 $149.5 \mathrm{~cm}$, 体重 $34 \mathrm{~kg}$.

既往歴：65歳頃より喀血があり，1987年に気管 支拡張症と診断された。当時の検査では, 胸部レン トゲン写真で左下葉の気管支拡張症，左舌区の無気 肺あるいは炎症性浸潤，左胸膜肥厚，右肺過膨張を
認めた。 CTでは左下葉および右上葉の気管支拡張 症，左舌区無気肺を認め, 気管支鏡検査では左 B4, B5の発赤，腫脹がみられたが，可視範囲では閉塞 はなく出血もみられなかった。肺機能検査は肺活量 $2.29 l$ (\%肺活量 $75 \%$ )，1 秒量 $1.48 l$ (\% 1 秒量 $83 \%$ ) であった。動脈血ガス分析值は $\mathrm{pH} 7.37, \mathrm{PaCO}_{2}$ $42 \mathrm{mmHg}, \mathrm{PaO}_{2} 82 \mathrm{mmHg}, \mathrm{HCO}_{3} 25 \mathrm{mmol} \cdot l^{-1}, \mathrm{BE}$ $0 \mathrm{mmol} \cdot l^{-1}$ であった。とぎき喀血がある以外は息 切れ, 呼吸困難の症状もなく近医で去痰剤の内服治 療のみで経過観察されていた。

1991 年, 交通事故で左大腿骨頸部骨折を起こし, 脊髄くも膜下麻酔により観血的整復術を受けたが特 に問題はなかった。

現病歷：1995年 5 月頃より下腹部膨満感があり, 10月不正出血を起こした. 子宮体癌の疑いのもとに, 
子宮鏡検査, 子宮内膜掻破術により確定診断した後, 根治術が予定された。術前の胸部レントゲン写真は 1987 年当時と変化はなかった。呼吸に関するほかの 検査はなされていなかった。

入院後経過：11月 9 日の入院時血圧は $115 / 67$ $\mathrm{mmHg}$ であった。翌日より咳，痰(血痰はなかった) があり, 39〜 $40{ }^{\circ} \mathrm{C}$ 発熱を認めたため内科を受診 し, 喀痰培養の結果, 気管支拡張症の混合感染の診 断で抗生物質の投与を受けた。11日の血液検査では 白血球 $15,900 \cdot \mathrm{mm}^{-3}$, CRP 8.2 であった。11月 15 日 には体温は $36.5 \sim 37^{\circ} \mathrm{C}$, 白血球は $8,900 \cdot \mathrm{mm}^{-3}$ に低 下し，咳も消失したため，翌 16 日に産婦人科医の麻 酔による子宮鏡検査が行われた。

麻酔経過：前投薬は投与していない。入室時血圧 は 148/80mmHg, 脈拍 $95 \mathrm{bpm}$ であった。砕石位を とり消毒後, ジアゼパム $3.5 \mathrm{mg}$ を静注するとともに, マスクで酸素 $3 l \cdot \mathrm{min}^{-1}$ の吸入を開始した。 2 分後呼 吸抑制のないことを確認しケタミン $30 \mathrm{mg}$ を静注し た。血圧が 206/116 m m $\mathrm{mg}$ に上昇し，脈拍は $130 \mathrm{bpm}$ となった。呼吸抑制, 舌根沈下が生じ, $\mathrm{SpO}_{2}$ が急激に低下し $55 \%$ になった。経口エアウェ イを挿入したが改善しなかった。心室性期外収縮が 頻発し, ジアゼパム投与後 7 分で麻酔科医に応援の 要請があった。ただちに麻酔科医が駆けつけてみる と, 口腔内に鮮血が充満しており，気道出血による 窒息を考え，ただちに気管挿管を行った。 $100 \%$ 酸 素による用手換気で $\mathrm{SpO}_{2}$ は $99 \%$ に回復した。気管 内吸引により鮮血が多量に吸引された。血圧は 210/110mmHg と依然と高值のためニカルジピン 0.5mg を静注した。血圧は 155/75mmHgに低下した。 気管内吸引後に撮影した胸部 X 線写真では術前陰 影に加え右肺に少量の血液の流入と思われる陰影 を認めた。この時点での動脈血ガス分析值は $\mathrm{pH}$ 7.134, $\mathrm{PaCO}_{2} 74 \mathrm{mmHg}, \mathrm{PaO}_{2} 330 \mathrm{mmHg}, \mathrm{BE}$ $6.3 \mathrm{mmo} \cdot l^{-1}, \mathrm{HCO}_{3} 24.3 \mathrm{mmo} \cdot l^{-1}$, 血液検査は赤血 球 $401 \times 10^{4} \cdot \mathrm{mm}^{-3}$, Hb $11.0 \mathrm{~g} \cdot \mathrm{d} l^{-1}$, Ht $35 \%$ と術前 と変化はなかった，気管支鏡では，気管分岐部に少
量の血液と, 左主気管支から下葉支に血液の充満を 認め，それらの血液を吸引した。左下葉支入口部に 血餅が付着していたが，除去することにより再出血 の危険性があるため残した，右側気管支は末梢まで 十分に開通しており血液は主気管支壁にわずかに認 められた。正確な出血部位は確認できなかったが, その可能性の高い左下葉にトロンビン 1 万単位を止 血目的で注入した，気管支鏡施行中の収縮期血圧は $150 \mathrm{mmHg}$ 以下であり, 麻酔薬の追加投与は行わな かった．新たな出血もなく，気管支鏡終了時には覚 醒し, $\mathrm{SpO}_{2} 100 \%$, 血圧 $140 / 78 \mathrm{mmHg}$, 脈拍 $98 \mathrm{bpm}$ で努力呼吸もなく安定しているため，気管支 鏡終了 5 分後 (ジアゼパム投与 1 時間後)に抜管した。 抜管後の血圧は 136/79mmHg, $\mathrm{SpO}_{2} 100 \%$ ，脈拍 $79 \mathrm{bpm}$ であったが，子宮鏡検査は中止し，病室に帰 した。その後喀血することはなかったが，子宮鏡検 査をせず， 12 月 7 日，春髄くも膜下麻酔により子宮 単純摘出術, 両側附属器摘出術, 大網部分切除術, 動注用カテーテル挿入を施行し, 問題なく終了した。

\section{II 考察}

今回の症例は 10 年前よりときどき喀血を繰り返 していたが，特に重篤となることはなく近医で投薬 のみで経過観察されており，ケタミン投与後に気道 出血を起こす可能性は予測困難であった。

気管支拡張症の過半数に喀血が認められ，喀血は ときに緊急を要する事態に陥る。本疾患は年齢に関 係し中高年に比較的多い ${ }^{2)}$. 本報告例は 65 歳頃より 時おり喀血を認めていた，気管支拡張症の出血の要 因には気道感染が多いといわれている ${ }^{2)}$. 今回の気 道出血も術前に発熱, 白血球, CRP 上昇と気道感染 が疑われ，炎症が誘因となった可能性が考えられる. また出血量は炎症(細菌，血沈， CRP) とは関係がな く，血圧に最も影響され， $160 \mathrm{mmHg}$ 以上で $100 \mathrm{~m} l$ 以上の出血が起こると報告されている ${ }^{2)}$. 今回の症 例は，高歯であり，喀血の既往があるうえに，感染 症も加わっており，易出血となっていたと思われた。 
ジアゼパムで導入しケタミンを投与した後に呼吸抑 制，舌根沈下を起こし低酸素血症，高二酸化炭素血 症となり血圧が上昇したうえにケタミンの交感神経 刺激作用でさらに血圧が上昇したと推測された。血 圧のクリティカルポイントを超えたため肺出血を起 こし, 気道閉塞が生じ低酸素血症, 高二酸化炭素血 症がさらに進行し悪循環に陥ったものと考えられた。

喀血を伴う気管支拡張症の麻酔管理上の問題点と しては血圧の管理が重要である，以前に骨折に対し て脊髄くも膜下麻酔で問題なく手術が施行された が，脊髄くも膜下麻酔は血圧の上昇がなく呼吸に対 しても影響が少ないためと思われる。後日の子宮摘 出術の麻酔も脊髄くも膜下麻酔で合併症なく安全に 行われ，今回の子宮鏡の麻酔も脊髄くも膜下麻酔が 安全であったと思われた。手術術式によっては全身 麻酔を選択しなければならない場合もあり，咳嗽， 喀痰を伴う気管支拡張症例では術中の多量の分泌 物，それによる気道閉塞などの肺合併症，術後の肺 炎と管理に難渋することがある ${ }^{3)}$ 。また自覚症状の ない症例でも術中, 術後に気道分泌が過剩になった 報告もあり，術前からの理学療法をはじめ周術期管 理には注意が必要である ${ }^{4)}$.

気道出血した場合 48 時間以内に気管支鏡検査を 施行すれば多くの症例で出血を確認できるといわれ ている ${ }^{2)}$. 今回，出血直後の気管支鏡では左下葉から
の出血は認められたが明らかな出血点は判明しなかっ た．出血の治療としては多くが止血剤投与による保 存的治療で改善するが，大量喀血の場合には効果が 確実な気管支動脈塞栓術を行う ${ }^{5)}$ ，今回は気管支鏡 を施行した時点ではすでに出血は止まっていたが, 再出血の予防のためにトロンビンの気管支内投与を 行った。その後入院期間中に出血は起こらなかった。

喀血による気道閉塞に対して気道確保，吸引の目 的で気管内チューブを留置したままの方が安全な場 合もある。しかし抻管したままであると，出血した 場合自力で排出できず，また気管内チューブの刺激 で血圧が上昇するため再出血の可能性がありかえつ て危険である．本症例では完全覚醒後気管内チュー ブはただちに抜管し，これに伴い血圧も低下した。

\section{参考文献}

1）永井厚志：3. 気管支拡張症. 日本胸部 $53 ： 148$ 153, 1994

2）高橋典明, 山口美樹, 宮崎聖子ほか: 気管支拡張症に 伴う喀血症例の検討. 気管支学 $21: 11 \sim 15,1999$

3）三橋繁, 横崎典哉, 長谷川里砂ほか: 胃亜全摘術中よ り呼吸管理に難渋した気管支拡張症の 1 例。臨床麻酔 19 : 1203 1205, 1995

4）藤原雅雄, 白神豪太郎, 森健次郎：ヤング症候群患者 の麻酔経験. 麻酔 $44 ： 1695 \sim 1699,1995$

5）斎藤誠，田中浩一，中村治彦ほか：気道出血の対策． 気管支学 $18 ： 784 \sim 787 ， 1996$ 


\title{
A Case of Airway Hemorrhage after Intravenous Administration of Ketamine to a Patient with Bronchiectasis for Hysteroscopy
}

\author{
Mutsuko MATSUMOTO, Asako ISIKAWA, Takae NIGUMA, \\ Yutaka YAIDA, Masahiro OKAWA, Kenji SATO \\ Department of Anesthesiology, Himeji Red Cross Hospital
}

We experienced a case (76 years old) with uterine cancer who was scheduled for a hysteroscopy. She suffered from bronchiectasis for about 10 years but had no symptoms except minimum hemoptysis. Soon after diazepam $3.5 \mathrm{mg}$ and ketamine $30 \mathrm{mg}$ were administered intravenously, airway obstruction due to hemorrhage occurred and her $\mathrm{SpO}_{2}$ decreased to $55 \%$. Tracheal intubation was immediately performed by an anesthesiologist. There was no bleeding, and we administered thrombin 10,000 units to the lower left lobe by the bronchoscopy. The airway hemorrhage was suspected to be caused due to underlying infection of bronchi and the hypertension caused by the ketamine. Blood pressure should be well controlled during anesthesia, especially in patients with bronchiectasis, because hypertension may lead to fatal airway hemorrhaging.

Key Words : Airway hemorrhage, Bronchiectasis, Ketamin 